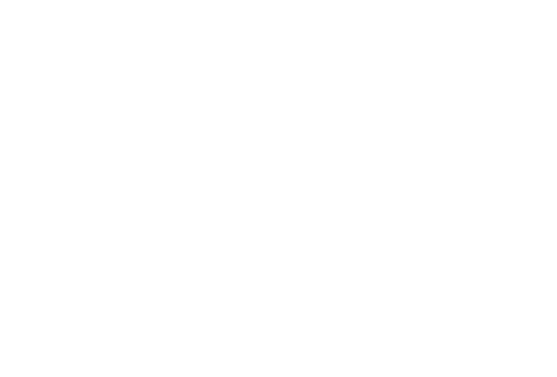

Annu. Rev. Entomol. 2010. 55:375-97

First published online as a Review in Advance on September 8, 2009

The Annual Review of Entomology is online at ento.annualreviews.org

This article's doi:

10.1146/annurev.ento.54.110807.090451

Copyright (c) 2010 by Annual Reviews.

All rights reserved

$0066-4170 / 10 / 0107-0375 \$ 20.00$

\section{Biorational Approaches to Managing Stored-Product Insects}

\author{
Thomas W. Phillips ${ }^{1}$ and James E. Throne ${ }^{2}$ \\ ${ }^{1}$ Department of Entomology, Kansas State University, Manhattan, Kansas 66502; \\ email: twp1@ksu.edu \\ ${ }^{2}$ USDA-ARS Grain Marketing and Production Research Center, Manhattan, Kansas 66502; \\ email: James.Throne@ars.usda.gov
}

\section{Key Words}

biological control, insect growth regulators, pheromones, physical control, sampling, decision-making

\begin{abstract}
Stored-product insects can cause postharvest losses, estimated from up to $9 \%$ in developed countries to $20 \%$ or more in developing countries. There is much interest in alternatives to conventional insecticides for controlling stored-product insects because of insecticide loss due to regulatory action and insect resistance, and because of increasing consumer demand for product that is free of insects and insecticide residues. Sanitation is perhaps the first line of defense for grain stored at farms or elevators and for food-processing and warehouse facilities. Some of the most promising biorational management tools for farm-stored grain are temperature management and use of natural enemies. New tools for computer-assisted decision-making and insect sampling at grain elevators appear most promising. Processing facilities and warehouses usually rely on trap captures for decision-making, a process that needs further research to optimize.
\end{abstract}




\section{INTRODUCTION}

Pheromones: chemical signals used between members of the same species, some of which are used in synthetic form for pest management

IPM: integrated pest management
Stored-product insects are serious pests of dried, stored, durable agricultural commodities, and of many value-added food products and nonfood derivatives of agricultural products worldwide. Stored-product insects can cause serious postharvest losses, estimated from up to $9 \%$ in developed countries to $20 \%$ or more in developing countries (88), but they also contribute to contamination of food products through the presence of live insects, insect products such as chemical excretions or silk, dead insects and insect body fragments, general infestation of buildings and other storage structures, and accumulation of chemical insecticide residues in food, as well as human exposure to dangerous chemicals as a result of pest control efforts against them. There are many safe, effective, and relatively simple prevention and control methods available to manage populations of stored-product insect pests without the use of chemical insecticides. In this review we describe and give updated information on biorational approaches to managing stored-product insect pests. These approaches either $(a)$ directly use biologically based materials, such as biologically derived insecticides or biological control organisms, to control pests or (b) take advantage of key aspects of the pest's biology to eliminate or manage pest populations through manipulation of the physical and biological environments of the target species.

Stored-product insects have been associated with human activities since the earliest civilizations, and methods for their diagnosis and control have been reported for over a century (60). Indeed, the first issue of the Annual Review of Entomology included an article on stored-product insects (79). Since then significant reviews have covered pheromones of stored-product insects (15) and alternatives to methyl bromide for controlling storage pests (31). Recent edited books have covered ecology and integrated pest management (IPM) of stored-product insects $(41,103)$ and alternatives to pesticides for controlling storage pests (104), and comprehensive textbooks on related topics are available $(38,92)$. New research and primary literature on stored-product insects continue to be generated at a steady pace by researchers at universities, but more so by scientists at government-sponsored research centers in North America, Europe, Asia, and Australia (82).

The motivation and influence behind current research on stored-product IPM are those that have led the field since the beginning, and more immediate objectives have been given impetus by government regulations, consumer demands, and broader commercial needs. The traditional objectives are to store grain and food in a wholesome way with minimum impact from insects or from chemical insecticides that may be used in pest control. More recently, the worldwide phaseout and ban of the fumigant insecticide methyl bromide, an effective compound for killing postharvest insects, under the international agreement of the Montreal Protocol has motivated research into various alternatives to replace methyl bromide (31). The U.S. Food Quality Protection Act of 1996 focused on evaluating all registered pesticides, with particular attention to worker and consumer exposures to chemical residues; thus, reduction or elimination of residues in grain and foods was targeted by research for nonchemical alternatives (82). In addition to regulatory pressures for low-risk control of stored-product insects, consumers and governments around the world set standards for organic food, which should be derived from raw products that are free of human-made chemicals, among other requirements (120). Thus, research on chemical-free or biologically based methods to control storedproduct insects was encouraged and supported. This current review briefly covers the basic literature on our topic and is an update on more recent literature, focusing on biologically based approaches that have proven efficacy, are legally registered for use or are in the registration process, and have the greatest chance of commercial adoption by the grain, food, and pest control industries. Our review focuses on cereal grains and their products, rather than oilseeds and edible legumes, although the material is 
relevant to all durable stored agricultural products, of both plant and animal origin, that may be threatened by stored-product insects. Mites (Acarina) are not covered in depth, although biorational management tactics for insect pests are generally relevant to mites. Vertebrate pests, although of substantial economic and public health considerations, are reviewed elsewhere (41).

\section{HABITATS AND GUILDS OF STORED-PRODUCT INSECTS}

\section{Bulk Commodities}

The stored-grain environment is unique among most agroecosystems in that it is entirely human-made and not subject to rapid and extreme changes in environmental conditions. After harvest, grain is placed into storage in a structure such as a steel bin, concrete silo, a flat storage such as a steel building, or simply on a concrete slab with the grain covered with plastic. Steel bins may vary in size, with volumes that hold 30 to 8000 tons of grain. A concrete silo at a grain elevator typically may contain 500 to 800 tons of grain, and a flat storage, in which grain is dumped into a large pile in a protected building, may contain as much as 80,000 tons of grain. Fall-harvested crops such as corn and rice in temperate climates are dried with forced-air heating to reduce moisture content shortly after harvest and before being placed into storage. Stored cereal grains may be cooled with ambient aeration after storage, if aeration equipment is available, to lower temperature to reduce insect population growth. Temperature-based preventive pest management is more challenging in grain stored in tropical and subtropical climates. Both temperature and moisture content of grains should be carefully controlled during storage to maintain quality, and grain should not be exposed to rainfall or direct sunlight that would cause degradation.

There are complexes of insect pests that infest grain, and the particular species present depend upon the type of grain. All cereal grains and many stored legumes are infested by pests whose larvae either feed and develop inside the kernel or develop outside intact kernels. The internal-feeding insects have been referred to historically as primary pests, while those feeding outside the kernels on broken and fine material have been referred to as secondary pests. Some of the most serious economic insect pests of wheat are internal feeders such as the lesser grain borer, Rhyzopertha dominica (F.) (Coleoptera: Bostrichidae), which lays eggs outside the kernel and the larvae bore into the kernel to complete development to the adult stage, and the rice weevil, Sitophilus oryzae (L.) (Coleoptera: Curculionidae), which lays eggs directly inside the kernel. External-feeding pests of wheat are the red flour beetle, Tribolium castaneum (Herbst) (Coleoptera: Tenebrionidae); the rusty grain beetle, Cryptolestes ferrugineus (Stephens) (Coleoptera: Laemophloeidae); and the sawtoothed grain beetle, Oryzaephilus surinamensis (L.) (Coleoptera: Silvanidae). Insects most commonly found in shelled corn (maize) are internal feeders such as the maize weevil, Sitophilus zeamais Motschulsky, and the Angoumois grain moth, Sitotroga cerealella (Olivier) (Lepidoptera: Gelechiidae); externalfeeding pests include C. ferrugineus; the flat grain beetle, C. pusillus (Schönherr); and $O$. surinamensis. Major internal-feeding pests of rice are $R$. dominica, S. oryzae, and S. cerealella.

Insects' long association with grain coincides with the development of agriculture in civilized human societies, as evidenced in grain found at archaeological sites such as the ruins of ancient Rome (53). Most stored-grain insects are found worldwide because grain has been transported around the world for millennia. Thus, there are few quarantine issues with stored-product insect pests. A notable exception is the khapra beetle, Trogoderma granarium Everts (Coleoptera: Dermestidae), which is perhaps the most notorious stored-product insect of quarantine significance (37). Stored-grain insects are also common in nonagricultural areas; for example, Sitophilus weevils and storedproduct bostrichids can infest seeds and other structures of wild plants (23). Stored-grain
Aeration: the practice of drawing outside air into a grain storage bin or other structure for the purpose of changing the temperature or moisture content of the stored grain

External-feeding pests: insects whose larvae develop outside sound grain kernels, are generally unable to damage sound kernels, and predominantly require broken kernels, grain dust or milled grain products for food

Internal-feeding pests: insects whose larvae develop inside seeds and kernels of grain and generally cause damage to otherwise sound kernels of grain

Stored products: dried, durable agricultural products that can be kept without spoilage for weeks or months without refrigeration 


\section{PSOCOPTERA}

Psocoptera have long been known to occur in stored grain and grain-processing facilities, but they were not considered pests of substance until the early 1990s in Australia and China and until the 2000s in the United States. They pose a challenge because little is known about them and because their biology and control differ from that of other stored-product pests. For example, many of the pest species are parthenogenetic and have rapid population growth. Their behavior is also unique, e.g., they will leave a bin of low-moisture grain at night to rehydrate outside the bin and then move back inside the bin in the morning. Most of our control technologies have been developed for control of beetle and moth pests, and psocids respond in varying ways to these control techniques. Psocids are naturally tolerant to the fumigant phosphine, apparently because they delay egg hatching until the phosphine dissipates. Behavior can also affect efficacy of insecticides. For example, lower mobility in Liposcelis bostrychophila appears to make it more tolerant than L. entomophila to surface insecticides. Psocids historically were believed to be associated with high-moisture products, but some species develop more quickly at lower relative humidities. insects are predaceous on other insects, particularly the dorsoventrally flattened pest species in the genera Cryptolestes and Oryzaephilus that naturally occur under the bark of trees (61). Book or bark lice (Psocoptera) are now considered serious pests of stored products (see sidebar, Psocoptera) (77), and they have rapidly evolved resistance to phosphine fumigant (75).

\section{Value-Added Food Products}

Many of the same species of stored-product insects found in bulk storage of raw commodities also occur in processing facilities such as flour and feed mills, food-manufacturing facilities and bakeries, as well as in all the structures in which value-added food products are stored or transported (37). However, the relative importance of some species changes after the grain is processed. Processing of grain products typically begins with grinding the grain, or milling, followed by fractionation of the various milled products such as bran, endosperm, and germ for segregation and ultimate different end uses. The milled grain products are immediately vulnerable to infestation by insects that are usually unable to breach an intact grain kernel. Thus, these external-feeding insects of the bulk commodity habitat are the predominant pest insects infesting the habitats of processed foods. Internal-feeding insects, such as $R$. dominica or S. oryzae, find host materials mostly in the bulk storage bins of processing plants and thus are not commonly encountered as a problem for the finished product, although internal feeders such as Sitophilus can be pests of finished pasta products. Pest insects such as Tribolium flour beetles; flat grain beetles in the genera Cryptolestes and Oryzaephilus; and the complex of stored-product pyralid moths (Lepidoptera: Pyralidae), including the Indianmeal moth, Plodia interpunctella (Hübner), the almond moth, Cadra cautella Walker, and Ephestia species thrive in mills, food-processing facilities, and warehouses with processed food products. The milled grain products and the dust from the processing sustain these populations of external-feeding grain pests.

The physical habitat of food-processing facilities and warehouses are ideal for storedproduct insects when combined with preground grains. Although the desired product of the processing is usually moving within a closed system of conveyors, belts, and chutes, the constant grinding and milling of grain in such buildings generates dust in the air that then settles in places that are difficult to clean. In addition, processing machinery and conveying systems have so-called dead-spaces, where food products accumulate, do not move, and can be cleaned only when machines are stopped and disassembled. Thus, food accumulates in areas where stored-product insects can breed, and their control and management is inherently problematic for value-added food facilities (9).

\section{MANIPULATING THE PHYSICAL ENVIRONMENT}

\section{Sanitation and Exclusion}

Sanitation of grain and food storage facilities and the effective exclusion of stored-product 
insects from such structures and from food packages are the keys to preventive management of storage insects. For bulk-stored grain it is imperative that newly harvested commodities be stored in clean bins and not be loaded into bins that contain older products that may harbor insects. Harvesting equipment, transportation containers, loading areas, and storage bins need to be as clean as possible before harvest and storage of the new crop, and sometimes it is prudent to treat the surfaces of inside walls, floors, and ceilings of such structures and machinery with a residual insecticide to kill any insects that may remain following the previous storage season $(7,92)$. Thus, mechanical, electrical, and structural engineering aspects of buildings and bins containing stored products must be considered during construction and maintenance of such structures. In mills and other food-processing facilities it follows that the raw grains, which may be stored for several months before processing and might harbor growing stored-product insect populations, be physically located in bins that are separated from the processing areas and even further separated from the packaging and finished-product warehouse or loading areas. Lighting can attract insects of all kinds, including stored-product insects (100), to buildings; thus it is recommended that light fixtures not be mounted directly over outside doors but that lighting be mounted on poles away from, but directly illuminating, buildings. Window screens and doors to the outside of buildings, as well as those between major processing, bulk storage, and warehouse areas in a building or complex of buildings, need to be in good service to reduce movement of insect pests. Machinery should be situated in such a way that it can be easily accessed and dismantled for thorough cleaning. Cleaning in large processing plants should employ careful sweeping and/or vacuum cleaning of food debris for complete removal, rather than conducting blowdowns of debris in order to concentrate it for removal as this can result in spreading dust and food products to inaccessible areas such as ledges and tops of beams where insects can easily breed without disturbance. Double-wall construction and suspended ceilings should be avoided or removed so that hidden voids in food plants do not retain food debris and cryptic insect infestations (65).

Effective exclusion of stored-product insects from storage bins, processing plants, and finished food packages can prevent infestation. Roofs and sidewalls of storage bins should be sealed to prevent insect entry as well as moisture damage and mold growth following water leaks from rain. Bin sealing is critical for effective use of chemical fumigants when needed. Proper roof ventilation and subfloor intake aeration vents are needed for proper temperature and moisture management of grain (see below), but these must be equipped with effective insectproof screening when in use and sealed when needed for fumigation (17). Packaging materials for finished food products at both wholesale and retail levels of marketing must be resistant to penetration by postharvest insect pests (69). Two commonly encountered groups of storedproduct insects that invade food packages are those that can actually chew through and penetrate the packaging material and those species that invade packages through breaches or other weak points in the seals or closures of the package (42). Thus, food packages need to be sealed very well to deter invaders and need to be constructed of durable materials to resist penetrators. Technology has been developed to impregnate food packaging material with low-risk insecticides (90), and research has been conducted on insect repellents applied to packages to reduce infestation (43), but commercial adoption of insect-repellent or insecticidal food packages has not occurred, likely owing to low cost-effectiveness and low potential for consumer acceptance.

\section{Temperature Management}

Insect populations can be managed by manipulating the temperature of their environment. The maximum rate of growth and reproduction for most insects occurs between 25 and $33^{\circ} \mathrm{C}$ and is reduced at temperatures above and below this range, with complete cessation of 
Irradiation: the practice of applying electromagnetic radiation of certain wavelengths and energy to a commodity for the purpose of pest control development and eventual death at approximately 13 and $35^{\circ} \mathrm{C}(29)$. Use of aeration to cool grain and reduce insect population growth rate is regularly used in steel bins but is less common in concrete silos and flat storages in the United States. Aeration of large governmentowned flat storages in China is common. Aeration can be useful even for summerharvested crops because grain temperatures can be reduced 3 to $4^{\circ} \mathrm{C}$ by running aeration fans at night; however, research on summer aeration for controlling grain insects in the United States has had mixed results $(6,36)$. Summer aeration reduced insect populations in some years, but not in other years (6). This may have been due to temperatures at the grain surface, where many insects occur, being lowered from lethal levels of $40^{\circ} \mathrm{C}$ in warm climates to more favorable levels for insects by summer aeration. Aeration can be effective for pest management in fall-stored crops in cool climates. Aeration is compatible with other control strategies, such as chemical or biological control.

Use of automatic aeration controllers, which turn fans on and off based on grain and ambient temperatures, can be more efficient than manual aeration for cooling grain (10). In Texas, grain temperatures were 8 to $10^{\circ} \mathrm{C}$ cooler in September and October and 3 to $6^{\circ} \mathrm{C}$ cooler during the rest of the storage period when using automatic rather than manual aeration of rice, and resulting insect populations were also lower in bins using automatic aeration. Chilled aeration, the process of blowing refrigerated air through a grain mass, can reduce grain temperatures and insect populations below those achievable using ambient aeration or no aeration (47), but chilled aeration is not commonly used for bulk grains because of cost. A solar adsorption cooling system was successfully tested for chilling bulk grain in China and may provide a more cost-effective alternative (62).

Various forms of heating have been used to kill insects in bulk grain (12), such as microwave or infrared radiation. However, the methods have not been widely used because of the time required to treat large amounts of grain. Recent studies show efficacy of infrared catalytic heaters for disinfestation of rice (78), but again the method is not widely used. A propane heater is effective for disinfestation of empty grain bins by raising the temperature to $50^{\circ} \mathrm{C}$ for $2 \mathrm{~h}(115)$; however, the cost is much greater compared with using insecticides (116).

Heat has long been used to kill insects in mills $(12,22,65)$. With the impending loss of the fumigant methyl bromide, heat is gaining popularity as an alternative method of disinfestation. Either the whole plant or problem areas may be heated. Generally, the goal is to raise the temperature of the mill to $50-60^{\circ} \mathrm{C}$ for $24 \mathrm{~h}$, which can be effective for insect control (94). A challenge in heat disinfestation is uniformity of temperature throughout the treated area, which may be improved with fans. One valid concern with use of heat disinfestation, which is shared anecdotally among food industry sanitarians, is that older buildings may be structurally damaged and that some equipment is heat sensitive (31).

Although freezing can be effective for insect control, it is generally not used because of cost. However, freezing is one of the few options available for disinfestation of durable organic commodities, such as grains, infested with insects. Usually 2-3 weeks of storage in commercial freezers is required for disinfestation $(48,49)$.

\section{Irradiation}

Irradiation of durable stored products is legal in most countries and can be conducted using ionizing radiation such as gamma rays, which have the potential to dislodge electrons from chemical bonds in molecules, and nonionizing radiation such as radio frequencies, microwaves, or infrared rays, which do not break bonds but essentially heat the product and the insects by vibrating bonds in water (40). Irradiation could be used to disinfest product entering a grain storage system or as a remedial treatment for infested product in a storage system. Infrared irradiation is the same as heating, described above, and can be applied to the air and surfaces of structures as well as directly to commodities 
that will tolerate it. Microwaves and radio frequency also heat water in the insects or the surrounding commodity, causing death by cellular disruption, but these need to be directed at a moving commodity in a thin layer over the individual kernels and thus cannot be applied to a whole structure. High-energy microwaves have been applied to flowing grain in a pilot-scale trial with effective insect kill and no negativequality effects on the grain (85), but commercial adoption is cost-prohibitive and would require much higher throughput levels of grain than those studied.

Ionizing radiation at dosages of up to $10 \mathrm{kGy}$ (kilogrey) for grain is safe for the commodity and usually has delayed mortality of insects through cell cycle disruption following damage to DNA. Typically, doses of $0.4 \mathrm{kGy}$ or less are required to be effective for most insects (39). Insect eggs and young larvae exposed to effective doses of gamma rays fail to develop to adults, and treated adults are reproductively sterile. Sources of ionizing radiation are from radioisotopes such as cesium or cobalt, or they are generated like $\mathrm{X}$-rays via an electron beam (40). Unfortunately, adoption of ionizing irradiation treatments for postharvest agricultural products has been minimal to nil in the United States owing to public concerns regarding the safety of radioisotope facilities and public misperception that treated food becomes radioactive and that those eating the food could suffer radiation poisoning. Also many countries and customers have zero tolerance for live insects in grain or finished products, and ionizing irradiation does not cause immediate acute insect mortality.

\section{Controlled and Modified Atmospheres}

Exposure of insects to toxic concentrations of atmospheric gases has been practiced for centuries and has been promoted in recent years as a biorational substitute for chemical fumigations (74). A controlled atmosphere is one in which a target concentration of a particular gas is maintained, and a modified atmosphere is one in which there is a dynamic change in atmospheric gases over time (i.e., the relative abundance of atmospheric gases changes from tolerable to toxic). Target gas concentrations for insect toxicity are $3 \%$ or less of oxygen and/or $60 \%$ or more of carbon dioxide. Thus, one type of controlled atmosphere would be addition of $\mathrm{CO}_{2}$ to levels above $60 \%$ for $24 \mathrm{~h}$ or more, or flushing an exposed space with an inert gas such as nitrogen to displace $\mathrm{O}_{2}$ below $3 \%$. A low-oxygen atmosphere can also be achieved and maintained by applying vacuum, or low pressure, to an infested commodity in a gas-tight chamber so that all the atmospheric gases decrease, including oxygen $(64,82)$. The dynamic gas concentration of a modified atmosphere can be achieved under hermetic storage of an infested commodity in which the activity of aerobic arthropods and microbes consume the $\mathrm{O}_{2}$ in a gas-tight structure and generate $\mathrm{CO}_{2}$, resulting in a decrease in $\mathrm{O}_{2}$ from ambient concentration of about $20 \%$ to below $10 \%$ and a increase in $\mathrm{CO}_{2}$ from an ambient concentration of $0.04 \%$ to approximately over $20 \%$ in a matter of weeks to months. Toxicity responses of insects to controlled or modified atmospheres are similar to those with chemical fumigants: $\mathrm{Ex}$ posure times needed for effective kill decrease as temperature increases and as the most lethal concentration (e.g., lower $\mathrm{O}_{2}$ or higher $\mathrm{CO}_{2}$ ) is approached. As with chemical fumigants, life stages most susceptible to altered atmospheres are those most active, the larvae and adults, whereas eggs and pupae are typically more tolerant of controlled atmospheres. Cereal grains and oilseeds treated with controlled or modified atmospheres experience virtually no adverse effects.

Application of controlled or modified atmospheres presents several logistical challenges, although once overcome the methods present opportunities. Paramount to the success of these methods is having a gas-tight or minimally permeable chamber or storage structure in which to treat the infested commodity. Treatment of a typical mill or food plant would be impractical in most cases because these buildings are too leaky to maintain the needed gas concentrations. Well-sealed grain bins, either
Controlled or modified atmosphere: an alternative mixture of atmospheric gases that is insecticidal, due to having very low oxygen levels or high carbon dioxide, and imposed on an infested commodity in a gas-tight container 
Diatomaceous earth (DE): fossilized remains of the silicon dioxide skeletons of diatoms, which are aquatic algae, that are insecticidal as desiccants metal or concrete, that are filled with grain and thus have $40 \%$ or less free air space are good candidates for $\mathrm{CO}_{2}$ treatment if gas can be maintained for several days at temperatures over $25^{\circ} \mathrm{C}$. The best structure for controlled atmosphere treatment is a gas-tight chamber that can maintain the desired gas concentration for the times needed. Hence, the broadscale adoption of controlled or modified atmosphere treatments is impeded by the lack of suitable chambers at food companies and by the limitation any chamber of a reasonable size would place on throughput of a treated commodity.

The cost of gases needed for controlled atmospheres may also be a hindrance to adoption. $\mathrm{CO}_{2}$ is expensive and must be available in large supply for certain applications. $\mathrm{N}_{2}$ for use in low $\mathrm{O}_{2}$ treatments is less expensive and can be generated from ambient air, in which it is close to $80 \%$ concentration, via membrane-adsorption technology (74). Technology exists for the generation of low $\mathrm{O}_{2}$ and high $\mathrm{CO}_{2}$ burner gas through cleaned effluent from an exothermic gas-burning generator (102) that can deliver a controlled atmosphere to a structure for days. A low-cost alternative to a gas-tight chamber made of rigid construction is the use a flexible polyvinyl chloride bag, or cocoon, that can hold from 1 to 20 tons of infested commodity and be treated with $\mathrm{CO}_{2}$ or subjected to low $\mathrm{O}_{2}$ by attachment of a vacuum pump to achieve low pressure $(74,82)$. Hermetic storage for generating a dynamic modified atmosphere has been demonstrated extensively in Israel and parts of Asia and Africa, and provides a means of safe storage in locations where electricity or access to gases or permanent storage structures is limited (74).

\section{Humidity Control and Desiccation}

Most insects that occur in stored grain thrive at moisture contents of 12 to $15 \%$ (45), so reducing moisture content is an option for control. Regions with low-moisture-content grain and low temperatures at harvest, such as Canada and the extreme northern United States, where typical moisture content of wheat when placed in bins is $7 \%$, have few insect problems. However, drying can cause cracks in grain kernels (66), making the grain more susceptible to insect infestation (110). In general, artificial drying has not been used as an insect control method.

Control of stored-product insects by desiccation can be facilitated by treatment of infested commodity and spaces with diatomaceous earth (DE). DE represents the fossilized silicon dioxide skeletons of diatoms, which are unicellular aquatic algae. Deposits of diatoms from ancient seas and lakes are plentiful for mining in various locations worldwide. DE kills insects following contact exposure by absorbing the hydrocarbons from their cuticles, which causes dehydration and ultimate death (54). The activity of DE is increased under low humidity and higher temperatures. An enhanced DE was developed that utilizes added silica gel, a finer and more homogenous source of silicon dioxide (55). DE is nontoxic to vertebrates and is even a common food additive and food-processing agent with the designation GRAS (generally regarded as safe). The efficacy of DE varies significantly among its geographic source locations where it is mined, so users must follow label instructions closely to ensure control (54). Application of DE at effective rates to an entire grain mass can cause a significant loss in bulk density, thus lowering the quality and value of the treated grain (56); care should be taken to use minimal effective rates or to treat problem areas only (e.g., the top or bottom layers of the grain mass). Other disadvantages of DE are that workers can be bothered by high dust levels, and the abrasive property of the material may slow or damage conveying equipment if care is not taken. Nevertheless, DE represents one of the most effective and safest nonchemical methods for controlling storage insects, and in the United States DE is organically compliant for several commercial formulations.

\section{Impact and Removal}

Turning grain, which involves moving grain from one bin to another, with a pneumatic conveyor can result in $70-100 \%$ mortality of 
larval and adult beetle pests, depending on stage and species (124). However, grain is not usually turned in farm storages, and elevators turn grain only to add phosphine fumigant to kill insects or to cool the grain. Any movement of grain can cause cracking, which makes the grain more susceptible to insects. Cleaning of grain, through sieving or so-called scalping, has been proposed as a method for limiting population growth of external-feeding pests by removing broken material, but there is a lack of evidence from controlled field tests that this practice is cost-effective (34). Entoleters, or impact machines, are widely used in flour mills to kill insects in flour (89). They are less useful for killing insects in whole grains or in coarse-grained products because of damage to the product.

\section{BIOLOGICALLY BASED CONTROLS}

\section{Pheromones and Other Semiochemicals}

Attractant pheromones, which are intraspecific chemical signals, and other attractant semiochemicals have been identified for over 40 species of stored-product insects over the past 40 years $(15,18,81,83)$. There are two broad categories of pheromone systems recognized in stored-product insects, which follow life-history models for insects in general. Species with short-lived, usually nonfeeding adult stages utilize female-produced sex pheromones in which a receptive adult female "calls" by releasing one or more attractant compounds and one or more males respond upwind to the pheromone after which mating occurs. The female sex pheromone system is exemplified in many species of stored-product moths, predominated by species in the Pyralidae, subfamily Phycitinae, and beetles in the families Anobiidae, Bruchidae, and Dermestidae. Clothes moths in the family Tineidae have interesting pheromone systems in which males orient toward larval food sources and then produce pheromones in a resource-based manner (108), while females produce attractant pheromones for males (107). Stored-product species with long-lived, feeding adults, all examples of which are beetles, utilize maleproduced aggregation pheromones that attract both males and females. Release and perhaps production of the pheromones by males is closely tied to feeding or contact with food: Males locate food, produce pheromones, attract females and other males, and mate; females oviposit at that site, where larvae ultimately develop. Aggregation pheromone systems have been described for stored-product pests in the families Bostrichidae (20, 24), Curculionidae (86, 122), Cucujidae and Silvanidae (76), and Tenebrionidae $(46,106)$. Pheromones provide highly sensitive tools for insect detection, because a pheromone trap may detect the presence of an insect while numerous traditional samples would detect none, and pheromones are highly specific to a target species.

Pheromones are commercially available for approximately 20 species of stored-product insects as slow-release formulations of lures to be used in monitoring traps (83). Among those that can be purchased, the most commonly used pheromones are those for $P$. interpunctella, the cigarette beetle, Lasioderma serricorne (F.) (Coleoptera: Anobiidae), the red and confused flour beetles, Tribolium castaneum and T. confusum Jacquelin du Val, respectively, and the warehouse beetle, Trogoderma variabile Ballion (Coleoptera: Dermestidae). The efficacy of pheromone-baited sticky traps vary according to their placement within a building (i.e., proximity to walls, floors, and ceilings), and other flat landing sites enhance the response of $P$. interpunctella males to pheromone-baited traps (73). For beetles that tend to land and crawl to an odor source, traps are designed to sit on a floor or flat surface and capture insects that walk into the trap, which eventually become stuck to the trapping surface or ensnared inside the trapping receptacle. Barak \& Burkholder (11) developed a trap with horizontal layers of corrugated cardboard in which responding beetles walked through the tunnels of corrugations to reach a cup of oil into which they fell and became suffocated. A 
popular alternative design is what appears as a ramp-and-pitfall trap, in which beetles walk to the trap, climb up an inclined side of the trap, and then fall into a receptacle of oil (68). The oil in these floor traps serves both as a trapping medium and as a pheromone synergist or additive attractant, as many formulations are grain-derived $(84,86)$. Odors from larval foods that also serve as attractants for adult moths, technically considered kairomones, were developed for monitoring females of $P$. interpunctella and other stored-product moths $(67,96)$.

When attractant traps are used properly in value-added food systems they can be a key component of IPM. Detection is the simple determination of the presence or absence of a pest species using pheromone traps, and monitoring refers to the collection of trap capture data over space and time in a building. Use of pheromone traps in bulk grain situations is not as informative as direct and indirect sampling of grain (see below), and pheromone-trapping will usually result in high trap captures that are not informative, or worse, in the case of aggregation pheromones that attract females, might attract pest insects into the grain. Traps in foodprocessing and warehouse facilities need to be distributed fairly evenly over the entire area of interest at a density that is cost-effective for the manager, and they must be checked for insects on a regular basis over time, perhaps every one or two weeks throughout the season of interest or the entire year. Application of trapping data with spatial analysis or geographic information software can be used to visualize locations in a building with high or low probability of encountering a pest insect or infestation $(70,71)$, but sometimes simple manual observation of collected trap capture data over time will be highly useful information to a pest manager. Traps provide relative population samples. The manager should be attentive to increases in insect numbers in traps at one or more locations relative to other locations, and to increases or decreases in numbers at one time compared to past sampling times. In addition, pheromone traps can be used to help determine the efficacy of a management tactic, such as fumigation or heat treatment, by comparing trap captures before and after the treatment (84).

Pheromones can also be used to suppress and control pest populations of stored-product insects. Mass-trapping males with a sex pheromone can theoretically control a population if a large number of males are removed from the population (59). Male moths such as P. interpunctella can inseminate an average of six females in their lifetimes; thus, a few surviving males in a population under mass-trapping treatment could maintain the reproductive rate of the population at a level similar to that without mass-trapping. Despite the perceived challenge of effective mass-trapping of storage moths, several reported examples are known from Europe (83) and from the United States for food stored for retail (16). The attract-and-kill, or attracticide, method is similar to mass-trapping, but instead of using traps, which can saturate with dead moths and need servicing, an insecticide-treated surface is coupled with the pheromone lure so that males contact the insecticide briefly and then die soon after $(72,83)$. Mating disruption, in which a treatment area is saturated with an unnaturally high concentration of synthetic sex pheromone and males are unable to locate and successfully mate with females, has proven successful for stored-product moths under controlled conditions (101), and recently in commercial field settings $(82,95)$. Government registration of a pheromone for the expressed purpose of controlling an insect pest population is required in the United States. Primary registration of the synthetic sex pheromone of stored-product moths, Z,E-9,12-tetradecadienyl acetate, was recently granted. This registration, which considers the pheromone an insecticide yet does not set illegal residue levels for exposed foods as is done with many other insecticides, allows for grains and foods to be present when using this pheromone to control stored-product moths (28). This is perhaps the first registration of a sex pheromone for mating disruption for indoor use in the United States. 


\section{Insect Natural Enemies}

There is a guild of insect natural enemies associated with stored-product insects, and most are as adapted to human-based habitats as are their prey and hosts. The literature on insect natural enemies has been reviewed by Schöller \& Flinn (97) and Schöller et al. (98). Several species of parasitoid wasps from the Pteromalidae are solitary ectoparasitoids of internal-feeding grain-infesting species of beetles, and similarly there are several common species of Ichneumonidae and Braconidae as ecto- and endoparasitoids associated with stored-product Lepidoptera. Some species of free-living predatory beetles, true bugs (Heteroptera: Anthocoridae), and mites prey on any life stage of numerous species of stored-product insect pests that they can subdue and consume. Populations of parasitoids and predators in storage systems display delayed density dependency in their dynamics that are typical of other predator-prey and parasitoid-host systems in other insect communities, and population declines of storedproduct pest species are typically followed by increases in these natural enemy populations.

It is legal to add insect parasitoids and predators to bulk grain and to food warehouses in the United States under regulations passed by the Food and Drug Administration (FDA) and the U.S. Environmental Protection Agency (EPA) (25). In short, insect natural enemies were technically designated insecticides so they could be regulated, and then they were exempted from a requirement of a tolerance level in food. The relevant FDA regulation for filth in food refers to the allowable number of insect fragments in finished food, such as flour for bread-making. Thus, fragments of pest insects and those of natural enemies are not differentiated, and the level cannot be legally exceeded. These key regulations allow the addition of insect natural enemies to stored-products systems and present an opportunity for biologically based management of storage pests with careful and knowledgeable use by pest managers. Commercial suppliers of natural enemies for stored-product pest management are limited at present, but examples of success on a small scale exist and the potential for further development is great $(38,98)$.

\section{Microbial Insecticides}

A number of insect pathogens have been tested for control of stored-product insects, but none is in common use because of lack of sufficient, broad-spectrum efficacy. Many tests have been conducted to synergize pathogens with other control technologies, particularly those that might be expected to increase efficacy of pathogens, such as DE (51) by presumably abrading the cuticle, or grain varietal resistance by delaying larval development (113), both of which might make the insect more susceptible to the pathogen. Laboratory evaluations of the commercially available fungi Beauveria bassiana and Metarbizium anisopliae and the bacterium Bacillus thuringiensis (Bt), alone or in conjunction with another insecticidal material such as $\mathrm{DE}$, generally result in complete control of only some stages of some species, while other stages or species are poorly controlled $(2,51,113)$. Bt generally has been most effective against Lepidoptera and Diptera, although some strains show increased efficacy for beetles (2); however, efficacy is still poor compared with conventional insecticides. This lack of efficacy limits the use of pathogens in commercial applications. Bt has been registered for control of stored-product Lepidoptera for decades, but it has rarely been used because it does not control beetle pests. An effective granulosis virus specific for $P$. interpunctella was described and a method for low-cost mass-production was developed (121), but commercial adoption has been limited.

Spinosad is an insecticide derived from metabolites in the fermentation of the actinomycete bacterium Saccharopolyspora spinosa Mertz and Yao (Actinomycetales: Actinomycetaceae) (109). Spinosad is currently registered by the U.S. EPA (27) with a residue tolerance concentration of $1.5 \mathrm{ppm}$ for use on stored grain in both conventional and organic formulations. However, spinosad has not been released for 
Insect growth regulators (IGRs): synthetic insecticides that mimic insect hormones and act by disrupting the normal development of immature stages of target insects use by the manufacturer as of this writing due to the lack of full approval for tolerance levels on stored grain by all international trading partners with the United States as called for under the Codex Alimentarius (internationally recognized standards or guidelines for food safety). There is much interest in the use of spinosad on stored grain because other residual insecticides registered in the United States and elsewhere have limited efficacy against the major pest of stored wheat, $R$. dominica, either because of simple lack of efficacy or because of development of resistance. Spinosad is effective for seasonlong control of $R$. dominica in stored wheat; it is highly toxic to larvae of many stored-product insects and shows good compatibility with insect natural enemies $(21,105,119)$.

\section{Botanical Insecticides}

There is a plethora of studies on the use of plant extracts or whole plant materials for insect control, but few are used on a commercial scale (91). Farmers often use homegrown or naturally occurring plant materials for insect control in developing countries. Problems with botanical insecticides are lack of consistency, safety concerns, and sometimes odor. It is often falsely assumed that because a plant material is used as a food flavoring or medicine that extracts from the material will be safe for human consumption. Various extracts from the neem tree, Azadirachta indica, collectively referred to as the insecticide Neem, are commercially available botanical insecticides, and local formulations have been widely used in some parts of the world for stored-product insect control (57). However, commercial formulations show only moderate levels of efficacy $(1,52)$. Crude pea flour, and the protein-rich fraction of field peas, Pisum spp., as well as that of other food legumes (e.g., species of Pissum, Phaseolus, and Vignia), are toxic and repellent to stored-product insects $(13,30)$. Direct application of protein-enriched pea flour to bulk grain at $0.1 \%$ by weight resulted in substantial reductions in stored-grain beetle populations (44), and broadscale application of pea flour to the inside of mills reportedly resulted in insect control, but such control was not at commercially acceptable levels like those achieved with synthetic fumigants.

Pyrethrum, a commercial mixture of compounds derived from Chrysanthemum cinerariifolium, is perhaps the most successful botanical insecticide throughout all modern pest control, and this is certainly the case for stored products. The active ingredients from pyrethrum are called pyrethrins. Synergized pyrethrum commonly contains the synergist piperonyl butoxide, commonly referred to as $\mathrm{PBO}$, which suppresses metabolic degradation of pyrethrins in the insect. Synergized pyrethrum is commonly used as an aerosol in flour mills (117) and is usually combined with another insecticide that has longer residual activity because the pyrethrum achieves only quick knockdown of insect pests at best, while the other insecticide with which it is combined provides longer activity (5). Organically compliant pyrethrum, which lacks any synthetic synergist and is extracted from chrysanthemum flowers by methods approved by the USDA National Organic Program, has been registered in the United States in recent years and shows potential for managing stored-product insects (16), but registration of a stored-product use is pending and suitable efficacy has yet to be investigated.

\section{Insect Growth Regulators}

Insect growth regulators (IGRs) used in storedproduct systems in the United States and elsewhere include the insect juvenile hormone analogs methoprene, hydroprene, and pyriproxyfen (8). All three compounds mimic the effects of sustained increased titer of insect juvenile hormone by disrupting normal development between larval instars and in metamorphosis from larvae to pupae and then from pupae to normal adults. These IGRs are not directly toxic to adults, although their potential effects on reproductive sterility have not been fully investigated. Another key attribute to these IGRs is their low levels of toxicity to mammals and inherent high level of food safety. 
Methoprene was considered so nontoxic that it was exempted from a requirement of a tolerance by the EPA in the United States (26). The $\mathrm{LD}_{50}$ value of methoprene, when administered orally to rats, is $>34500 \mathrm{mg} / \mathrm{kg}$ (14). Methoprene applied at $1 \mathrm{ppm}$ to stored grain can retain insecticidal activity for over a year, perhaps owing to the environmentally protective environment of grain storage with regard to lack of temperature extremes and degradation from UV radiation.

Hydroprene is a structurally close isomer of methoprene with slightly more volatility and thus is considered to function better as an aerosol in space treatments of structures because of its ability to penetrate voids and spaces not treated directly. However, the structurally different pyriproxyfen has qualities slightly superior to hydroprene with regard to length of residual activity when applied to a variety of surfaces (7).

Despite safety and efficacy of IGRs for storage systems, they have not been widely adopted for stored grain when compared with traditional residual contact insecticides and fumigants, probably because of cost and lack of immediate knockdown. IGRs are widely used for aerosol treatment of food-processing and finished product storage areas, particularly when combined with pyrethrum or dichlorvos, which are added for immediate knockdown of active insect life stages. Increased use of IGRs may be attributed to pest managers seeking alternatives to methyl bromide. IGRs represent low-risk, biologically based insecticides with potential for more adoption in the food industry in the future. The chemically synthetic nature of IGRs, however, precludes them from use in strictly organic practices.

\section{Resistant Crops and Foods}

Varietal resistance was once considered a useful tool for management of stored-product insects but has not been used in the United States since the use of inexpensive insecticides such as malathion began in the 1970s. New varieties are not developed with resistance to stored-product insects in mind. Despite this, much variation in resistance to stored-product insects has been documented in commercially available crops.

Hull integrity is the best predictor of rice resistance to $R$. dominica (19). Phenolic content in corn, which may be related to kernel hardness, has been linked to resistance to the maize weevil, S. zeamais, and the larger grain borer, Prostephanus truncatus (Horn) (Coleoptera: Bostrichidae) (4). Variability in resistance of sorghum to storage insect pests has been correlated with integrity of the hull, hardness, and thickness of the endosperm (111). There is variability in wheat in resistance to stored-product insects, but the factors responsible for this are poorly understood (111). United States oat cultivars vary in their susceptibility to storage insect pests, with some varieties almost immune to insect population development (112). Again, the mechanism of resistance in oats has not been elucidated.

Transgenic avidin maize was developed for harvesting avidin for medical testing, but it is resistant to all storage insect pests against which it has been tested except for P. truncatus (58). Avidin kills insects by sequestering the vitamin biotin. Two Bt transgenic rice lines developed for control of the Asiatic rice borer, Chilo suppressalis Walker, incorporate cry $1 A a$ and $c r y 1 B$ genes and had mixed nontarget effects on storage insects (93). P. interpunctella did not survive on semolina produced from the two lines, while S. oryzae progeny production was reduced on one of the lines and progeny production of the psocid Liposcelis bostrychophila (Badonnel) (Psocoptera: Liposcelididae) was reduced on the other line.

\section{INTEGRATED PEST MANAGEMENT}

IPM is a decision-making process that utilizes information about the managed product, the insect pests occurring in the product, the abiotic factors of the system in which the product is managed, the tolerance for given numbers of pests or pest-related damage or contamination that may determine action levels, 


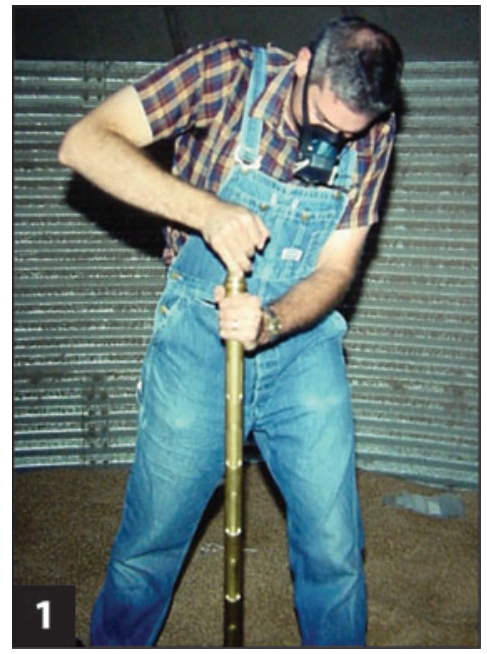

Figure 1

A technician inserts a grain trier into a mass of grain to remove a sample. The trier is a tube within a tube, such that grains enter the oblong opening once the device is fully inserted into the mass, and then the inner tube is turned to close the openings so that the entire sample can be withdrawn. Photo courtesy of Oklahoma State University.

spear-like metal tube used to obtain a sample of grain from a storage structure for the purpose of examining the grain for the presence of insects or to measure grain quality factors and the risks of various kinds that need to be considered in making management decisions. Sampling-based decision-making is the most straightforward form of IPM for relatively low-value and high-insect-tolerance bulk commodities, while near zero tolerance for insects

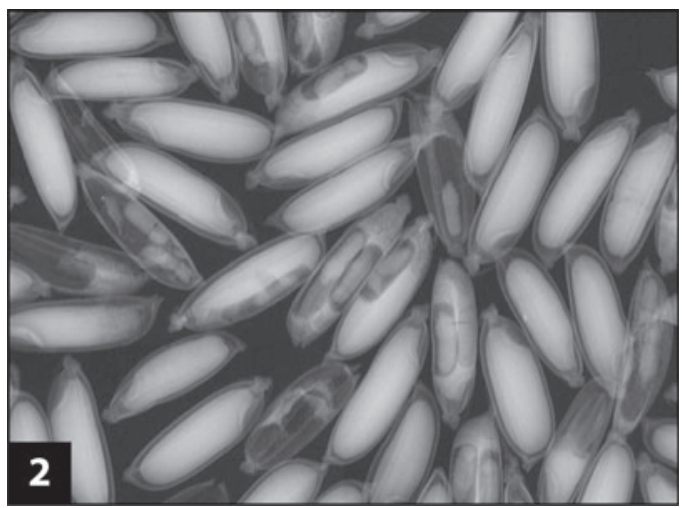

Figure 2

A digital X-ray image of rice kernels, some of which are infested with larvae, pupae, and teneral adults of the lesser grain borer, Rhyzopertha dominica. Photo courtesy of USDA.

and maximization of product quality drive IPM decision-making for value-added food products. Synthetic chemical insecticides, particularly the fumigant gas hydrogen phosphide, commonly referred to as phosphine, are commonly used in stored-product systems and will continue to be important tools. Nevertheless, in the context of biorational IPM, judicious use of chemical insecticides following knowledgebased decision-making is strongly advocated.

\section{Sampling and Population Estimation}

Sampling is an essential step in pest management because it allows the pest manager to take remedial actions only when pest populations reach levels that justify the cost of remediation. A number of techniques have been tested and many are used in stored grain. The most commonly used manual commercial method for grain stored in steel bins and grain in transit vehicles is the use of a grain trier, which is a metal spear up to $4 \mathrm{~m}$ in length that can be inserted into grain to withdraw a sample (Figure 1). Once the grain sample is removed with the trier, the external-feeding pests in the grain are removed by sieving. Mechanically operated pneumatic grain triers are routinely used to sample grain at points of sale in commercial transport by truck, rail, or barge. A deep-bin probe cup can be used to take samples from deeper in a grain mass (3), but this is not usually done because of the difficulty in pushing the probe into the grain mass. Sieving the sample to remove insects has the disadvantage of not sampling internal-feeding stages, which might make up a substantial proportion of all insects in a grain mass (80). These internal-feeding pests can be detected by various techniques (114), none of which is practical for farm-stored grain. Use of digital X-ray equipment may be practical at an elevator for detection of internal insects (Figure 2). The method is quick, but only a small sample can be scanned $(10 \times 10 \mathrm{~cm}$ area) and the equipment is relatively expensive (114). Image analysis of digital X-rays is accurate for detecting insects, but the number of false positives can be high (50). Probe traps 


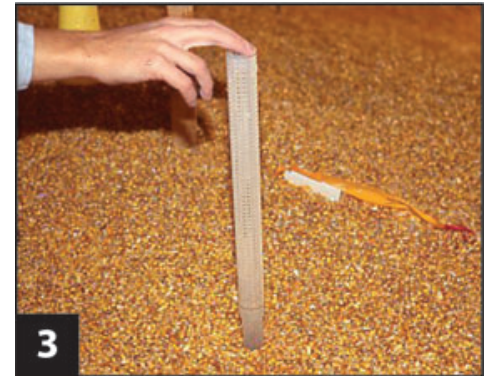

Figure 3

A grain probe trap (WB-II; Trece Inc., Adair, OK) inserted into a grain mass to sample live insects. The main body shaft of the trap has numerous holes through which insects fall inside the shaft, through a narrowed funnel bottom and into the collection tip for eventual recovery. Photo courtesy of USDA.

(Figure 3) have long been available for detection of insects in grain $(83,123)$, but they have not been widely used because of costs and safety concerns associated with bin entry. An automated probe trap (Insector ${ }^{\mathrm{TM}}$, OPI Systems, Inc., Calgary, Alberta, Canada), which incorporates infrared beams to count and determine species of insects falling into the traps (Figure 4), overcomes these shortcomings (99), although accuracy of species determination varies (35). Conventional probe-pitfall traps can be used throughout the grain mass (3), but they rarely are used in this manner because of the difficulty of pushing them into the grain mass and need for regular servicing. Insects in concrete silos can be sampled throughout the grain mass using a vacuum probe sampler (33) (Figure 5). Several automatic grain sampling devices are used in large terminal and export grain handling facilities to collect samples from flowing grain at regular time intervals (Figure 6) for the purpose of quality grading and insect detection (63).

The numbers of insects in grain samples are usually considered to be absolute estimates of population levels because they represent the number of insects in a given quantity of grain at one point in time. The disadvantage is that at normal infestation levels (two injurious insects per kilogram of wheat is considered actionable in wheat exported from the United States), few

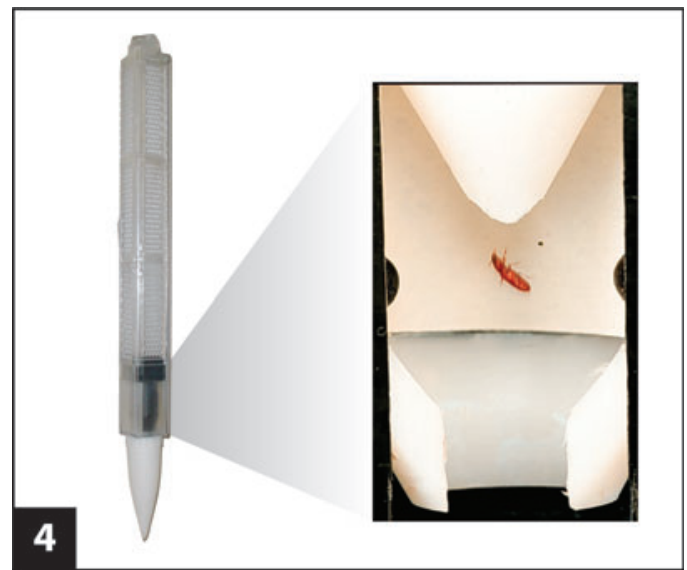

Figure 4

An electronic grain probe insect detector (Insector ${ }^{\mathrm{TM}}$, OPI Systems Inc., Calgary, Alberta, Canada) shown in full view, left, approximately $45 \mathrm{~cm}$ in length, and a cut-away view of the counting sensor near the bottom. The device is inserted into a grain mass; insects moving through the grain pass through the holes, fall through the shaft, and break an infrared beam of light at the sensor, as shown with this example of a red flour beetle, Tribolium castaneum. The device is connected to a computer system so that count data unique to a specific device are recorded with a date and time stamp to facilitate remote sensing with minimal servicing. Photo courtesy of USDA.

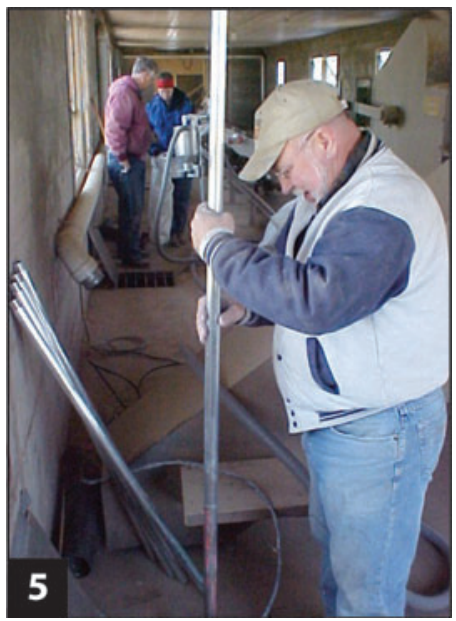

Figure 5

A powered vacuum probe grain sampler is applied from the top of a commercial concrete grain silo. The technician in the foreground is adding a $1.3-\mathrm{m}$ section of aluminum pipe that is pushed into the grain mass as the vacuum pump (not pictured) provides suction through a flexible hose, and samples of $3 \mathrm{~kg}$ are collected into a hopper (with technicians in the background) associated with each section of pipe. Photo courtesy of Oklahoma State University. 


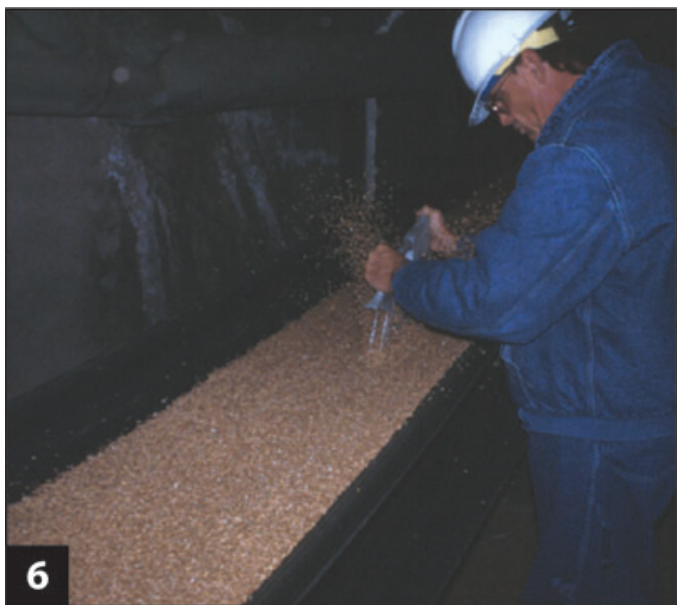

Figure 6

A technician uses an Ellis cup to collect a sample of grain from a fast-moving conveyor belt at a commercial grain storage facility. Samples can be collected manually, as here, or by automatic sampling devices while grain is moved between bins or when it is moved for export or brought in for initial storage. Photo courtesy of USDA.

insects are found in trier samples, so it is difficult to estimate population levels. For example, in a nine-month study of psocids in 32.6 tons of wheat stored in each of two steel bins, 547 psocids were found in trier samples (40 480-g samples taken every two weeks) and 77,502 psocids were found in Insector ${ }^{\mathrm{TM}}$ probe traps (10 traps inserted into the grain for one week every two weeks) (77). Although probe traps catch more insects, they are collecting insects as they move through the grain mass, so catches are affected by various factors such as behavior and abiotic conditions. These relative estimates of population level can be converted to absolute estimates of insect density by incorporating temperature into regression equations (118). A major problem with probe traps remains that they are only able to sample the surface of the grain. A vacuum probe sampling system overcomes this problem by taking a $3 \mathrm{~kg}$ sample of grain every $1.3 \mathrm{~m}$ in grain down to depths of $13 \mathrm{~m}$ or more (33).

Sampling of value-added finished products, especially when packaged for retail or wholesale marketing, is impractical and not done in practice. Sanitation and pest-free management are the goals of IPM in value-added food systems. Relative sampling of insect populations in food-processing facilities using pheromone traps or other insect sampling methods (e.g., light traps and product recall data) is the norm. Interpretation of trap captures at processing facilities to estimate population levels has been difficult, but recent attempts (71) to use the number of traps with no insects to estimate population levels look promising and practical at commercial food-processing facilities.

\section{Risk Assessment and Decision-Making}

IPM decision-making is based ultimately on risks of economic loss that encompass lost value from product defect, losses due to regulatory action following illegal practices, or increased costs due to pest control itself (87). Various computer-assisted tools have been developed for risk assessment and decision-making in farm-stored grain. The Stored Grain Advisor (SGA) expert system (32) can be used to aid in decision-making in farm-stored grain by inputting grain abiotic conditions (temperature and moisture content) and insect pest levels determined by sampling, and then models in the expert system predict future insect infestation levels and make recommendations for managing the grain. SGA was modified for use at grain elevators (33). Decision-making in processing facilities and warehouses is more difficult, and computer-assisted software to aid in this process is currently lacking. Managers of processing facilities historically relied on calendar-based fumigations for insect management, but, with the phaseout of methyl bromide, this is no longer true. Managers of these facilities are more likely now to rely on trap captures and direct inspections to make management decisions, but, as mentioned above, there is at present no uniform method for doing this. Biorational approaches to IPM in stored products should promote reduced risks while providing cost-effective pest management. 


\section{SUMMARY POINTS}

1. Stored-product insects are ubiquitous, essentially cosmopolitan, occurring in feral habitats as well as in human-made facilities, and infestation can be a continual year-round process that makes pest control difficult.

2. Grain, and its associated insect pests, has been transported across regions and around the world for millennia, so there are few quarantine issues yet common problems faced worldwide.

3. In developed countries, stored-product insects are an economic issue because of their presence and perception as filth and contamination to food, not because of quantitative losses to products in storage, which is more the case in developing countries.

4. Sanitation, the cleaning and removal of food debris that harbors insects, is the first line of defense in grain stored at farms or elevators and for food-processing and warehouse facilities.

5. Temperature management is one of the best bio-based methods for insect control in stored grain by cooling the grain to retard insect population growth with ambient air aeration with fans on bins, and by using hot forced air distributed through food-processing facilities to kill insects with heat.

6. A full toolbox of bio-based pest management methods is available for stored-product systems, including inert DE as an insecticidal desiccant, the microbial insecticide spinosad, highly safe synthetic IGRs, controlled and modified atmospheres as alternatives to traditional chemical fumigants, insect natural enemies that can regulate or control pest populations, and pheromones and other semiochemicals that can be used in traps for monitoring or applied as control tactics in mating disruption or attract-and-kill.

7. New tools for sampling grain for insect numbers and the application of these data in computer-assisted decision-making appear most promising at grain elevators. Systematic collection and use of insect infestation data for pest management decision-making in food processing also occurs.

\section{FUTURE ISSUES}

1. Further research is needed to determine the economics of cleaning as a management tool for stored grain to limit growth of external-feeding insect pests in particular.

2. Economic and pest management research should determine efficacy and costeffectiveness of exclusion of insects from grain storages as a management tool.

3. Interpretation of trap catch data in both stored grain and processing facilities needs further research to aid in pest management decision-making; continued development of automation in the collection and use of trap count data is also needed.

4. Research should optimize or further develop attractants to aid in monitoring of some stored-product insects and provide new tools for species for which attractants have not been identified. 
5. Commercial sources for obtaining biological control agents against stored-product insects are needed.

6. Work on molecular biology and genetics is needed to develop insect-resistant stored grains safe for human food or biopesticides that are effective and targeted at storedproduct insect pests as well as environmentally benign and safe for food and feed.

7. Research should identify methods for disinfesting and maintaining organically compliant commodities, such as optimizing the use of freezing.

8. The economic feasibility of biorational pest management methods should be determined so that storage managers can select the most cost-effective management methods.

\section{DISCLOSURE STATEMENT}

The authors are not aware of any affiliations, memberships, funding, or financial holdings that might be perceived as affecting the objectivity of this review.

\section{ACKNOWLEDGMENTS}

We sincerely thank our colleagues Frank Arthur, Paul Fields, Paul Flinn, and Manoj Nayak for their constructive comments on an earlier draft of this review. The authors appreciate financial institutional support from Oklahoma State University, Kansas State University, the USDA Agricultural Research Service, and various grant-funding programs from the USDA Cooperative State Research, Education and Extension Service. Mention of trade names or commercial products in this publication is solely for the purpose of providing specific information and does not imply recommendation or endorsement by Kansas State University or the U.S. Department of Agriculture.

\section{LITERATURE CITED}

1. Abate-Zeru S. 2001. The potential for natural products as grain protectants against stored product insects. MS thesis. Okla. State Univ., Stillwater. 68 pp.

2. Abdel-Razek AS. 2002. Comparative study on the effect of two Bacillus thuringiensis strains of the same serotype on three coleopteran pests of stored wheat. 7. Egypt. Soc. Parasitol. 32:415-24

3. Arbogast RT, Throne JE. 1997. Insect infestation of farm-stored maize in South Carolina: towards characterization of a habitat. F. Stored Prod. Res. 33:187-98

4. Arnason JT, Gale J, Conilh de Beyssac B, Sen A, Miller SS, et al. 1992. Role of phenolics in resistance of maize grain to the stored grain insects, Prostephanus truncatus (Horn) and Sitophilus zeamais (Motsch.). 7. Stored Prod. Res. 28:119-26

5. Arthur FH. 2008. Aerosol distribution and efficacy in a commercial food warehouse. Insect Sci. 15:133-40

6. Arthur FH, Casada ME. 2005. Feasibility of summer aeration to control insects in stored wheat. Appl. Eng. Agric. 21:1027-38

7. Arthur FH, Liu S, Zhou B, Phillips TW. 2009. Residual efficacy of pyriproxyfen and hydroprene applied to wood, metal and concrete for controlling stored-product insects. Pest Manage. Sci. 65:791-97

8. Arthur FH, Peckman PS. 2006. Insecticide space treatments in food plants. See Ref. 41, pp. 175-82

9. Arthur FH, Phillips TW. 2003. Stored-product insect pest management and control. In Food Plant Sanitation, ed. YH Yui, BL Bruinsma, JR Gorham, W Nip, PS Tong, P Ventresca, pp. 341-348. New York: Marcel Dekker

10. Arthur FH, Yang Y, Wilson LT, Siebenmorgen TJ. 2008. Feasibility of automatic aeration for insect pest management for rice stored in East Texas. Appl. Eng. Agric. 24:345-50 
11. Barak AV, Burkholder WE. 1985. A versatile and effective trap for detecting and monitoring storedproduct Coleoptera. Agric. Ecosyst. Environ. 12:207-18

12. Beckett SJ, Fields PG, Subramanyam BH. 2007. Disinfestation of stored products and associated structures using heat. In Heat Treatments for Postharvest Pest Control: Theory and Practice, ed. J Tang, E Mitcham, S Wang, S Lurie, pp. 182-237. Wallingford, UK: CAB Int.

13. Bodnaryk RP, Fields PG, Xie Y, Fulcher KA. 1999. U.S. Patent No. 5,955,082

14. Budavari S, O’Neil MJ, Smith A, Heckelman PE, Kinneary JF. 1996. The Merck Index: An Encyclopedia of Chemicals, Drugs and Biologicals. Whitehouse Station, NJ: Merck. 1741 pp.

15. Burkholder WE, Ma M. 1985. Pheromones for monitoring and control of stored-product insects. Annu. Rev. Entomol. 30:257-72

16. Campos-Figueroa M. 2008. Attract-and-kill methods for control of Indianmeal moth, Plodia interpunctella (Hübner) (Lepidoptera: Pyralidae), and comparisons with other pheromone-based control methods. PhD thesis. Okla. State Univ. 114 pp.

17. Casada ME, Noyes RT. 2001. Future bulk grain bin design needs related to sealing for optimum pest management: a researcher's view. Proc. Int. Conf. Control. Atmos. Fumig. Stored Prod., ed. EJ Donahaye, S Navarro, JG Leesch, pp. 457-65. Clovis, CA: Exec. Print. Serv.

18. Chambers J. 1990. Overview of stored-product insect pheromones and food attractants. F. Kans. Entomol. Soc. 63:490-99

19. Chanbang Y, Arthur FH, Wilde GE, Throne JE, Subramanyam BH. 2008. Methodology for assessing rice varieties for resistance to the lesser grain borer, Rhyzopertha dominica. F. Insect Sci. 8(16):1-5

20. Cork A, Hall DR, Hodges RJ, Pickett JA. 1991. Identification of major component of the male produced aggregation pheromone of the larger grain borer, Prostephanus truncatus (Horn) (Coleoptera: Bostrichidae). 7. Chem. Ecol. 17:789-803

21. Daglish GJ, Head MB, Hughes PB. 2008. Field evaluation of spinosad as a grain protectant for stored wheat in Australia: efficacy against Rhyzopertha dominica (F.) and fate of residues in whole wheat and milling fractions. Aust. 7. Entomol. 47:70-74

22. Dean G. 1913. Further data on heat as a means of controlling mill insects. 7. Econ. Entomol. 6:40-53

23. Edde PA, Phillips TW. 2006. Potential host affinities for the lesser grain borer, Rhyzopertha dominica: behavioral responses to host odors and pheromones and reproductive ability on non-grain hosts. Entomol. Exp. Appl. 119:255-63

24. Edde PA, Phillips TW, Robertson JB, Dillwith JW. 2007. Pheromone output by Rhyzopertha dominica (Coleoptera: Bostrichidae), as affected by host plant and beetle size. Ann. Entomol. Soc. Am. 100:83-90

25. Environ. Prot. Agency (EPA). 1992. Parasitic and predaceous insects used to control insect pests; exemption from a tolerance. Fed. Regist. 57:14644-46

26. Environ. Prot. Agency (EPA). 2003. Methoprene, watermelon mosaic virus-2 coat protein, and zucchini yellow mosaic virus coat protein; final tolerance actions. Fed. Regist. 68:34825-29

27. Environ. Prot. Agency (EPA). 2005. Spinosad; pesticide tolerance. Fed. Regist. 70:1349-57

28. Environ. Prot. Agency (EPA). 2006. Lepidopteran pheromones; exemption from a requirement of a tolerance. Fed. Regist. 71:45395-400

29. Fields PG. 1992. The control of stored-product insects and mites with extreme temperatures. F. Stored Prod. Res. 28:89-118

30. Fields PG. 2006. Effect of Pisum sativum fractions on the mortality and progeny production of nine stored-grain beetles. 7. Stored Prod. Res. 42:86-96

31. Fields PG, White NDG. 2002. Alternatives to methyl bromide treatments for stored-product and quarantine insects. Annu. Rev. Entomol. 47:331-59

32. Flinn PW, Hagstrum DW. 1990. Stored Grain Advisor: a knowledge-based system for management of insect pests of stored grain. AI Appl. Nat. Res. Manage. 4:44-52

33. Flinn PW, Hagstrum DW, Reed CR, Phillips TW. 2007. Stored Grain Advisor Pro: decision support system for insect management in commercial grain elevators. 7. Stored Prod. Res. 43:375-83

34. Flinn PW, McGaughey WH, Burkholder WE. 1993. Effects of fine material on insect infestation: a review. North Central Regional Research Pub. 332, OARDC Spec. Circ. 141. pp. 24-30. Wooster: Ohio Agric. Res. Dev. Cent., The Ohio State Univ. 
35. Flinn PW, Opit GP, Throne JE. 2009. Predicting stored grain insect population densities using an electronic probe trap. F. Econ. Entomol. 102:1696-704

36. Flinn PW, Subramanyam BH, Arthur FH. 2004. Comparison of aeration and spinosad for suppressing insects in stored wheat. 7. Econ. Entomol. 97:1465-73

37. Gorham JR, ed. 1991. Ecology and Management of Food Industry Pests. Arlington, VA: Assoc. Off. Anal. Chemists. 595 pp.

38. Hagstrum DW, Subramanyam B. 2006. Fundamentals of Stored-Product Entomology. St. Paul: AACC Int. $323 \mathrm{pp}$.

39. Hallman GJ, Phillips TW. 2008. Ionizing irradiation of adults of Angoumois grain moth (Lepidoptera: Gelichiidae) and Indianmeal moth (Lepidoptera: Pyralidae) to prevent reproduction, and implications for a generic irradiation treatment for insects. 7. Econ. Entomol. 101:1051-56

40. Halverson SL, Nablo SV. 2000. Radiation. See Ref. 104, pp. 381-400

41. Heaps JW, ed. 2006. Insect Management for Food Storage and Processing. St. Paul: AACC Int. 231 pp. 2nd ed.

42. Highland HA. 1991. Protecting packages against insects. See Ref. 37, pp. 345-50

43. Hou X, Fields P, Taylor W. 2004. The effects of repellents on penetration into packaging by storedproduct insects. 7. Stored Prod. Res. 40:47-54

44. Hou X, Fields PG. 2003. Granary trial of protein-enriched pea flour for the control of three storedproduct insects in barley. F. Econ. Entomol. 96:1005-15

45. Howe RW. 1965. A summary of estimates of optimal and minimal conditions for population increase of some stored products insects. 7. Stored Prod. Res. 1:177-84

46. Hussain A, Phillips TW, AliNiazee MT. 1994. Pheromone biology and factors affecting its production in Tribolium castaneum, ed. BR Champ, HJ Banks, E Highley, pp. 533-36. Proc. Sixth Int. Work. Conf. Stored-Prod. Prot. Canberra: CABI Press

47. Ileleji KE, Maier DE, Woloshuk CP. 2007. Evaluation of different temperature management strategies for suppression of Sitophilus zeamais (Motschulsky) in stored maize. 7. Stored Prod. Res. 43:480-88

48. Johnson JA. 2007. Survival of Indianmeal moth and navel orangeworm (Lepidoptera: Pyralidae) at low temperatures. F. Econ. Entomol. 100:1482-88

49. Johnson JA, Valero KA. 2003. Use of commercial freezers to control cowpea weevil, Callosobruchus maculatus (Coleoptera: Bruchidae), in organic garbanzo beans. 7. Econ. Entomol. 96:1952-57

50. Karunakaran C, Jayas DS, White NDG. 2003. Soft X-ray inspection of wheat kernels infested by Sitophilus oryzae. Trans. ASAE 46:739-45

51. Kavallieratos NG, Athanassiou CG, Michalaki MP, Batta YA, Rigatos HA, et al. 2006. Effect of the combined use of Metarbizium anisopliae (Metschinkoff) Sorokin and diatomaceous earth for the control of three stored-product beetle species. Crop Prot. 25:1087-94

52. Kavallieratos NG, Athanassiou CG, Saitanis CJ, Kontodimas DC, Roussos, et al. 2007. Effect of two azadirachtin formulations against adults of Sitophilus oryzae and Tribolium confusum on different grain commodities. 7. Food Prot. 70:1627-32

53. King GA, Gilbert MTP, Willerslev E, Collins MJ, Kenward H. 2009. Recovery of DNA from archaeological insect remains: first results, problems and potential. F. Archaeol. Sci. 36:1179-83

54. Korunic Z. 1998. Diatomaceous earths, a group of natural insecticides. 7. Stored Prod. Res. 34:87-97

55. Korunic Z, Fields PG. 1998. U.S. Patent No. 5,773,017

56. Korunic Z, Fields PG, Kovacs MIP, Null JS, Lukow OM, et al. 1996. The effect of diatomaceous earth on grain quality. Postharvest Biol. Technol. 9:373-87

57. Koul O, Isman MB, Ketkar CM. 1990. Properties and uses of neem, Azadirachta indica. Can. F. Bot. 68:1-11

58. Kramer KJ, Morgan TD, Throne JE, Dowell FE, Bailey M, Howard JA. 2000. Transgenic avidin maize is resistant to storage insect pests. Nat. Biotech. 18:670-74

59. Lanier GN. 1990. Principle of attraction-annihilation: mass trapping and other means. In BehaviorModifying Chemicals for Insect Management, Applications of Pheromones and other Attractants, ed. RL Ridgway, RM Silverstein, MN Inscoe, pp. 25-45. New York: Marcel Dekker

60. Levinson HZ, Levinson AR. 1985. Storage and insect species of stored grain and tombs in ancient Egypt. Zeits. für Angew. Entomol. 100:321-39 
61. Linsley EG. 1944. Natural sources, habitats, and reservoirs of insects associated with stored food products. Hilgardia 16:187-224

62. Luo H, Wang R, Dai Y, Wu J, Xu Y, Shen J, Fu J. 2006. Experimental investigation of a solar adsorption cooling system used for grain low temperature storage of grain. Acta Energ. Solaris Sin. 27:588-92

63. Manis JM. 1992. Sampling, inspecting, and grading. In Storage of Cereal Grains and Their Products, ed. DB Sauer, pp. 563-88. St. Paul: Am. Assoc. Cereal Chem. 4th ed.

64. Mbata GN, Phillips TW, Payton M. 2004. Mortality of eggs of stored-product insects held under vacuum: effects of pressure, temperature and exposure time. F. Econ. Entomol. 97:695-702

65. Mills R, Pederson J. 1990. A Flour Mill Sanitation Manual. St. Paul: Eagan. 164 pp.

66. Montross MD, Bakker-Arkema FW, Hines RE. 1999. Moisture content variation and grain quality of corn dried in different high-temperature dryers. Trans. ASAE 42:427-33

67. Mueller DK, Van Ryckeghem A. 2006. Pheromones for stored product insects. See Ref. 41, pp. 153-64

68. Mullen MA. 1992. Development of a pheromone trap for monitoring Tribolium castaneum. 7. Stored Prod. Res. 28:245-49

69. Mullen MA, Mowery SV. 2006. Insect-resistant packaging. See Ref. 41, pp. 35-38

70. Nansen C, Campbell JE, Phillips TW, Mullen MA. 2003. The impact of spatial structure on the accuracy of contour maps of small data sets. 7. Econ. Entomol. 96:1617-25

71. Nansen C, Meikle WG, Campbell J, Phillips TW, Subramanyam B. 2008. A binomial and speciesindependent approach to trap capture analysis of flying insects. F. Econ. Entomol. 101:1719-28

72. Nansen C, Phillips TW. 2004. Attractancy and toxicity of an attracticide for the Indianmeal moth, Plodia interpunctella (Lepidoptera: Pyralidae). F. Econ. Entomol. 97:703-10

73. Nansen C, Phillips TW, Sanders S. 2004. The effect of height and adjacent surfaces on captures of the Indianmeal moth, Plodia interpunctella (Lepidoptera: Pyralidae), in pheromone-baited traps. F. Econ. Entomol. 97:1284-90

74. Navarro S. 2006. Modified atmospheres for the control of stored-product insects and mites. See Ref. 41, pp. $105-45$

75. Nayak MK, Collins PJ. 2008. Influence of concentration, temperature and humidity on the toxicity of phosphine to the strongly phosphine-resistant psocid Liposcelis bostrychopbila Badonnel (Psocoptera: Liposcelididae). Pest Man. Sci. 64:971-76

76. Oehlschlager AC, Pierce AM, Pierce HD Jr, Borden JH. 1988. Chemical communication in cucujid grain beetles. F. Chem. Ecol. 14:2071-98

77. Opit GP, Throne JE, Flinn PW. 2009. Evaluation of five sampling methods for the psocids Liposcelis entomophila and L. decolor (Psocoptera: Liposcelididae) in steel bins containing wheat. F. Econ. Entomol. 102:1377-82

78. Pan Z, Khir R, Godfrey LD, Lewis R, Thompson JF, Salim A. 2008. Feasibility of simultaneous rough rice drying and disinfestations by infrared radiation heating and rice milling quality. F. Food Eng. 84:469-79

79. Parkin EA. 1956. Stored product entomology (the assessment and reduction of losses caused by insects to stored foodstuffs). Annu. Rev. Entomol. 1:223-40

80. Perez-Mendoza J, Flinn PW, Campbell JF, Hagstrum DW, Throne JE. 2004. Detection of stored-grain insect infestation in wheat transported in railroad hopper-cars. F. Econ. Entomol. 97:1474-83

81. Phillips TW. 1997. Semiochemicals of stored-product insects: research and applications. F. Stored Prod. Res. 33:17-30

82. Phillips TW. 2006. The science and technology of postharvest insect control: challenges, accomplishments and future directions. See Ref. 41, pp. 211-22

83. Phillips TW, Cogan PM, Fadamiro HY. 2000. Pheromones. See Ref. 104, pp. 273-302

84. Phillips TW, Doud CW, Toews MD, Reed C, Hagstrum D, Flinn P. 2001. Trapping and sampling stored-product insects before and after commercial fumigation treatments. In Proc. Int. Conf. Controll. Atmos., Fumigation Stored Prod., ed. EJ Donahaye, S Navarro, J Leesch, Fresno, CA., 29 Oct.-3 Nov. 2000, pp. 685-96. Clovis, CA: Executive Print. Serv.

85. Phillips TW, Halverson S, Bigelow T, Mbata G, Halverson W, et al. 2003. Microwave treatment of flowing grain for disinfestation of stored-product insects. In Advances in Stored Product Protection: Proc. 8th Int. Work. Conf. on Stored Prod. Protection, ed. PF Credland, DM Armitage, CH Bell, PM Cogan, E Highley, pp. 626-28. Wallingford, UK: CAB Int. 
86. Phillips TW, Jiang XL, Burkholder WE, Phillips JK, Tran-Quoc H. 1993. Behavioral responses to food volatiles by ecologically different stored-product Coleoptera, Sitophilus oryzae (Curculionidae) and Tribolium castaneum (Tenebrionidae). 7. Chem. Ecol. 19:723-34

87. Phillips TW, Noyes RT, Adam BD. 2002. Integrated pest management for grain elevators that supply the breakfast cereal industry: case studies and economic analysis. http://entoplp.okstate.edu/sprec/OSU-ElevatorIPM.pdf

88. Pimentel D. 1991. World resources and food losses to pests. See Ref. 37, pp. 5-11

89. Plarre R, Reichmuth C. 2000. Impact. See Ref. 104, pp. 401-17

90. Radwan MN, Allin GP. 1997. U.S. Patent No. 5,688,509

91. Rajandran S, Sriranjini V. 2008. Plant products as fumigants for stored-product insect control. F. Stored Prod. Res. 44:126-35

92. Reed CR. 2006. Managing Stored Grain to Preserve Quality and Value. St. Paul: AACC Int. 235 pp.

93. Riudavets J, Gabarra R, Pons MJ, Messeguer J. 2006. Effect of transgenic Bt rice on the survival of three nontarget stored product insect pests. Environ. Entomol. 35:1432-38

94. Roesli R, Subramanyam B, Fairchild FJ, Behnke KC. 2003. Trap catches of stored-product insects before and after heat treatment in a pilot feed mill. F. Stored Prod. Res. 39:521-40

95. Ryne C, Svensson GP, Anderbrant O, Löfstedt C. 2007. Evaluation of long-term mating disruption of Ephestia kuehniella and Plodia interpunctella (Lepidoptera: Pyralidae) in indoor storage facilities by pheromone traps and monitoring of relative aerial concentrations of pheromone. 7. Econ. Entomol. 100:1017-25

96. Sambaraju KR, Phillips TW. 2008. Responses of adult Plodia interpunctella (Hubner) (Lepidoptera: Pyralidae) to light and combinations of attractants and light. F. Insect Behav. 21:422-39

97. Schöller M, Flinn PW. 2000. Parasitoids and predators. See Ref. 104, pp. 229-71

98. Schöller M, Flinn PW, Grieshop MJ, Žd'árkova E. 2006. Biological control of stored-product pests. See Ref. 41, pp. 67-87

99. Shuman D, Weaver DK, Larson RG. 2005. Performance of an analytical, dual infrared-beam, storedproduct insect monitoring system. F. Econ. Entomol. 98:1723-32

100. Soderstrom EL. 1970. Phototactic responses of stored-product insects to various intensities of ultraviolet light. 7. Stored Prod. Res. 6:275-77

101. Sower LL, Witmer GP. 1977. Population growth and mating success of Indian meal moths and almond moths in the presence of synthetic sex pheromone. Environ. Entomol. 6:17-20

102. Storey CL. 1973. Exothermic inert-atmosphere generators for control of insects in stored wheat. F. Econ. Entomol. 66:511-14

103. Subramanyam B, Hagstrum DW, eds. 1996. Integrated Management of Insects in Stored Products. New York: Dekker. 426 pp.

104. Subramanyam B, Hagstrum DW, eds. 2000. Alternatives to Pesticides in Stored-Product IPM. Boston: Kluwer Academic. 437 pp.

105. Subramanyam BH, Toews MD, Ileleji KE, Maier DE, Thompson GD, Pitts TJ. 2007. Evaluation of spinosad as a grain protectant on three Kansas farms. Crop Prot. 26:1021-30

106. Suzuki T. 1981. Identification of the aggregation pheromone of the flour beetles, Tribolium castaneum and T. confusum (Coleoptera: Tenebrionidae). F. Agric. Biol. Chem. 45:1357-63

107. Takács S, Gries G, Gries R. 2001. Communication ecology of webbing cloths moth. 4. Identification of male- and female-produced pheromones. Chemoecology 11:153-59

108. Takács S, Gries G, Gries R. 2002. Where to find a mate? Resource-based sexual communication of webbing clothes moths. Naturwissenschaften 89:57-59

109. Thompson GD, Dutton R, Sparks TC. 2000. Spinosad—a case study: an example from a natural products discovery programme. Pest Manag. Sci. 56:696-702

110. Throne JE. 1993. Ability of older Cryptolestes ferrugineus (Coleoptera: Curculionidae) larvae to infest whole corn and long-term population growth on whole corn. F. Entomol. Sci. 28:175-81

111. Throne JE, Baker JE, Messina FJ, Kramer KJ, Howard JA. 2000. Varietal resistance. See Ref. 104, pp. 165-92

112. Throne JE, Doehlert DC, McMullen MS. 2003. Susceptibility of commercial oat cultivars to Cryptolestes pusillus and Oryzaephilus surinamensis. F. Stored Prod. Res. 39:213-23 
113. Throne JE, Lord JC. 2004. Control of sawtoothed grain beetles (Coleoptera: Silvanidae) in stored oats by using an entomopathogenic fungus in conjunction with seed resistance. 7. Econ. Entomol. 97:1765-71

114. Throne JE, Pearson TC. 2008. Detection of insects in grain. In Contribution for Integrated Management of Stored Rice Pests. Handbook, ed. R Mancini, MO Carvalho, B Timlick, C Adler, pp. 123-36. Lisbon: Inst. Investig. Cient. Trop.

115. Tilley DR, Casada ME, Arthur FH. 2007. Heat treatment for disinfestation of empty grain storage bins. 7. Stored Prod. Res. 43:221-28

116. Tilley DR, Langemeier MR, Casada ME, Arthur FH. 2007. Cost and risk analysis of heat and chemical treatments. F. Econ. Entomol. 100:604-12

117. Toews MD, Campbell JF, Arthur FH. 2006. Temporal dynamics and response to fogging or fumigation of stored-product Coleoptera in a grain processing facility. 7. Stored Prod. Res. 42:480-98

118. Toews MD, Phillips TW, Payton ME. 2005. Estimating populations of grain beetles using probe traps in wheat-filled concrete silos. Environ. Entomol. 34:712-18

119. Toews MD, Subramanyam B. 2004. Survival of stored-product insect natural enemies in spinosad-treated wheat. 7. Econ. Entomol. 97:1174-80

120. U.S. Dep. Agric. (USDA). 2000. National organic program: final rule. 7 CFR Pt. 205. Fed. Regist.

121. Vail PV, Tebbets JS, Cowan DC, Jenner KE. 1991. U.S. Patent No. 5,023,182

122. Walgenbach CA, Phillips JK, Faustini DL, Burkholder WE. 1983. Male-produced aggregation pheromone of the maize weevil, Sitophilus zeamais, and interspecific attraction between three Sitophilus species. 7. Chem. Ecol. 9:831-41

123. White NDG, Arbogast RT, Fields PG, Hillman RC, Loschiavo SR, et al. 1990. The development and use of pitfall and probe traps for capturing insects in stored grain. 7. Kans. Entomol. Soc. 63:506-25

124. White NDG, Jayas DS, Demianyk CJ. 1997. Movement of grain to control stored-product insects and mites. Phytoprotection 78:75-84 
(

\section{Contents}

Annual Review of

Entomology

Volume 55, 2010

Frontispiece

Mike W. Service ........................................................... xiv

The Making of a Medical Entomologist

Mike W. Service .................................................................. 1

Ecology of Herbivorous Arthropods in Urban Landscapes

Michael F. Raupp, Paula M. Shrewsbury, and Daniel A. Herms .......................19

Causes and Consequences of Cannibalism in Noncarnivorous Insects

Matthew L. Richardson, Robert F. Mitchell, Peter F. Reagel,

and Lawrence M. Hanks....

Insect Biodiversity and Conservation in Australasia

Peter S. Cranston

Ekbom Syndrome: The Challenge of "Invisible Bug" Infestations

Nancy C. Hinkle .....

Update on Powassan Virus: Emergence of a North American

Tick-Borne Flavivirus

Gregory D. Ebel

Beyond Drosophila: RNAi In Vivo and Functional Genomics in Insects Xavier Bellés

Dicistroviruses

Bryony C. Bonning and W. Allen Miller

Olive Fruit Fly: Managing an Ancient Pest in Modern Times

Kent M. Daane and Marshall W. Fohnson

Insect Silk: One Name, Many Materials

Tara D. Sutherland, James H. Young, Sarab Weisman, Cheryl Y. Hayashi,

and David 7. Merritt

Bayesian Phylogenetics and Its Influence on Insect Systematics

Fredrik Ronquist and Andrew R. Deans

Insect Fat Body: Energy, Metabolism, and Regulation

Estela L. Arrese and Fose L. Soulages 
Sex Differences in Phenotypic Plasticity Affect Variation in Sexual Size

Dimorphism in Insects: From Physiology to Evolution

R. Craig Stillwell, Wolf U. Blanckenhorn, Tiit Teder, Goggy Davidowitz,

Charles W. Fox

Facultative Symbionts in Aphids and the Horizontal Transfer of

Ecologically Important Traits

Kerry M. Oliver, Patrick H. Degnan, Gaelen R. Burke, and Nancy A. Moran

Honey Bees as a Model for Vision, Perception, and Cognition

Mandyam V. Srinivasan

Invasion Biology, Ecology, and Management of the Light Brown Apple

Moth (Tortricidae)

D.M. Suckling and E.G. Brockerhoff

Feeding Mechanisms of Adult Lepidoptera: Structure, Function, and

Evolution of the Mouthparts

Harald W. Krenn

Integrated Management of Sugarcane Whitegrubs in Australia:

An Evolving Success

Peter G. Allsopp

The Developmental, Molecular, and Transport Biology of Malpighian

Tubules

Klaus W. Beyenbach, Helen Skaer, and Julian A.T. Dow

Biorational Approaches to Managing Stored-Product Insects

Thomas W. Phillips and Fames E. Throne

Parallel Olfactory Systems in Insects: Anatomy and Function

C. Giovanni Galizia and Wolfgang Rössler

Integrative Taxonomy: A Multisource Approach to Exploring

Biodiversity

Birgit C. Schlick-Steiner, Florian M. Steiner, Bernbard Seifert,

Christian Stauffer, Erhard Christian, and Ross H. Crozier

Evolution of Plant Defenses in Nonindigenous Environments

Colin M. Orians and David Ward

Landscape Epidemiology of Vector-Borne Diseases

William K. Reisen

Role of Adhesion in Arthropod Immune Recognition

Otto Schmidt, Kenneth Söderbäll, Ulrich Theopold, and Ingrid Faye

Physical Ecology of Fluid Flow Sensing in Arthropods

férôme Casas and Olivier Dangles 
Managing Invasive Populations of Asian Longhorned Beetle and Citrus

Longhorned Beetle: A Worldwide Perspective

Robert A. Haack, Franck Hérard, Fianghua Sun, and Fean 7. Turgeon

Threats Posed to Rare or Endangered Insects by Invasions of

Nonnative Species

David L. Wagner and Roy G. Van Driesche

Malaria Management: Past, Present, and Future

A. Enayati and 7. Hemingway

Regulation of Midgut Growth, Development, and Metamorphosis

Raziel S. Hakim, Kate Baldwin, and Guy Smagghe

Cellulolytic Systems in Insects

Hirofumi Watanabe and Gaku Tokuda

\section{Indexes}

Cumulative Index of Contributing Authors, Volumes 46-55

Cumulative Index of Chapter Titles, Volumes 46-55

\section{Errata}

An online log of corrections to Annual Review of Entomology articles may be found at http://ento.annualreviews.org/errata.shtml 